\title{
Review of Exhumation and Implications for Hydrocarbon Exploration in Australia
}

\author{
A. Mavromatidis ${ }^{1}$ and P. Soupios ${ }^{*}, 2$ \\ ${ }^{I}$ Petroleum Development Oman, Muscat, Sultanate of Oman \\ ${ }^{2}$ Technological Educational Institute of Crete, Chania, Dept. of Natural Resources and Environment, Greece
}

\begin{abstract}
The subsidence history of sedimentary basins is recorded and can be relatively easily reconstructed from the preserved stratigraphic sequence. Uplift events, above sedimentary base level are expressed only by hiatuses or unconformities. Hence, quantifying the exhumation associated with uplift is intrinsically more problematic than quantifying the burial associated with the subsidence. Detailed study of the exhumation in basins is of particular significance since can provide crucial information about the petroleum exploration and for investigating the dynamic driving forces of basin uplift events. The aim of this article is to evaluate the magnitudes of exhumation in two well known petroliferous basins, the Cooper-Eromanga Basins of South Australia and Queensland, based on different techniques and to consider the implications for petroleum exploration.
\end{abstract}

Keywords: Exhumation, cooper-eromanga basin, hydrocarbon exploration.

\section{INTRODUCTION}

The Cooper and Eromanga Basins are Australia's largest onshore petroleum province, and are located in central and eastern Australia (Fig. 1).
The sediments of the Cooper Basin were deposited during Late Carboniferous-Triassic times in predominantly fluvial and lacustrine environments [1]. After the deposition of the Cooper Basin, in Late Triassic - Early Jurassic times,

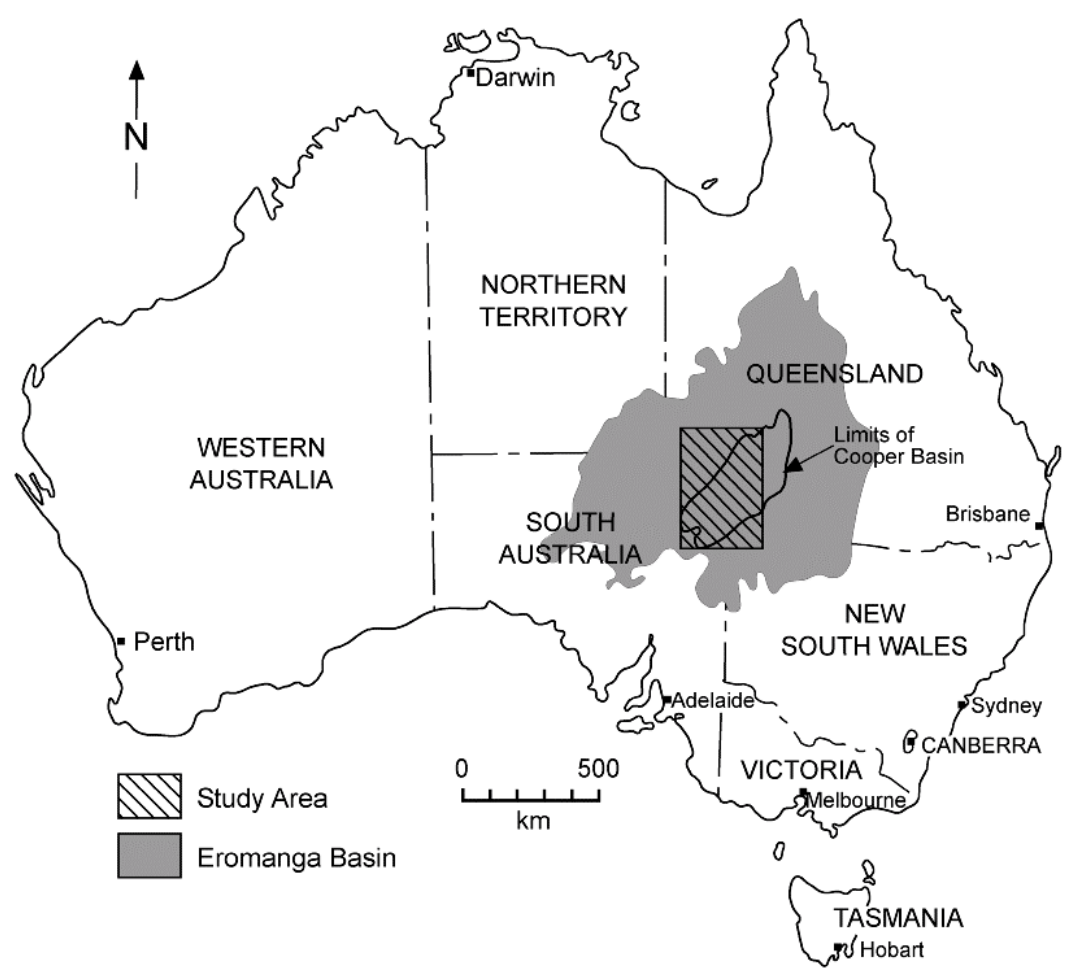

Fig. (1). Location map for the Cooper-Eromanga Basins [3, 4].

*Address correspondence to this author at the Technological Educational Institute of Crete, Chania, Dept. of Natural Resources and Environment, Greece; E-mail: soupios@nshan.chania.teicrete.gr an exhumational event took place which resulted in the basin wide Nappamerri unconformity [2-6] (Fig. 2). 


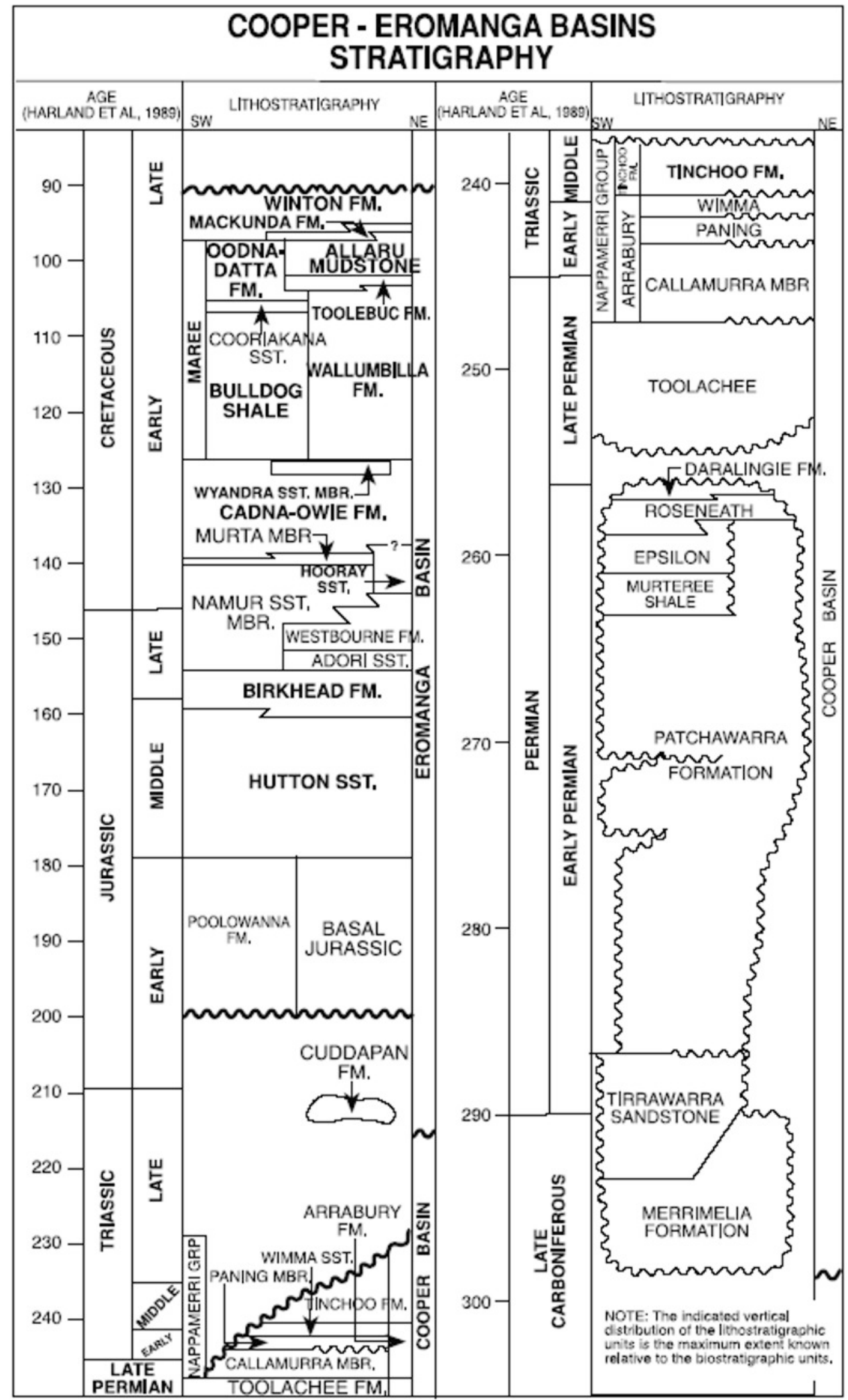

Fig. (2). Cooper-Eromanga Basins stratigraphic nomenclature $(\mathrm{FM}=$ Formation, $\mathrm{GRP}=$ Group, $\mathrm{MBR}=\mathrm{Member}, \mathrm{SST}=\mathrm{Sandstone})[5]$.

Subsequently, the Eromanga Basin sediments were deposited in Jurassic and Cretaceous times in fluvial-lacustrine and shallow marine environments [7]. After the deposition of the Eromanga Basin, sedimentation ceased and during the last 90 Myr the basin has been characterized by periods of exhumation and minor sedimentation [2, 8] (Fig. 2). A map showing the exact location of the wells where the methods of exhumation estimates were applied is presented in Fig. (3). 


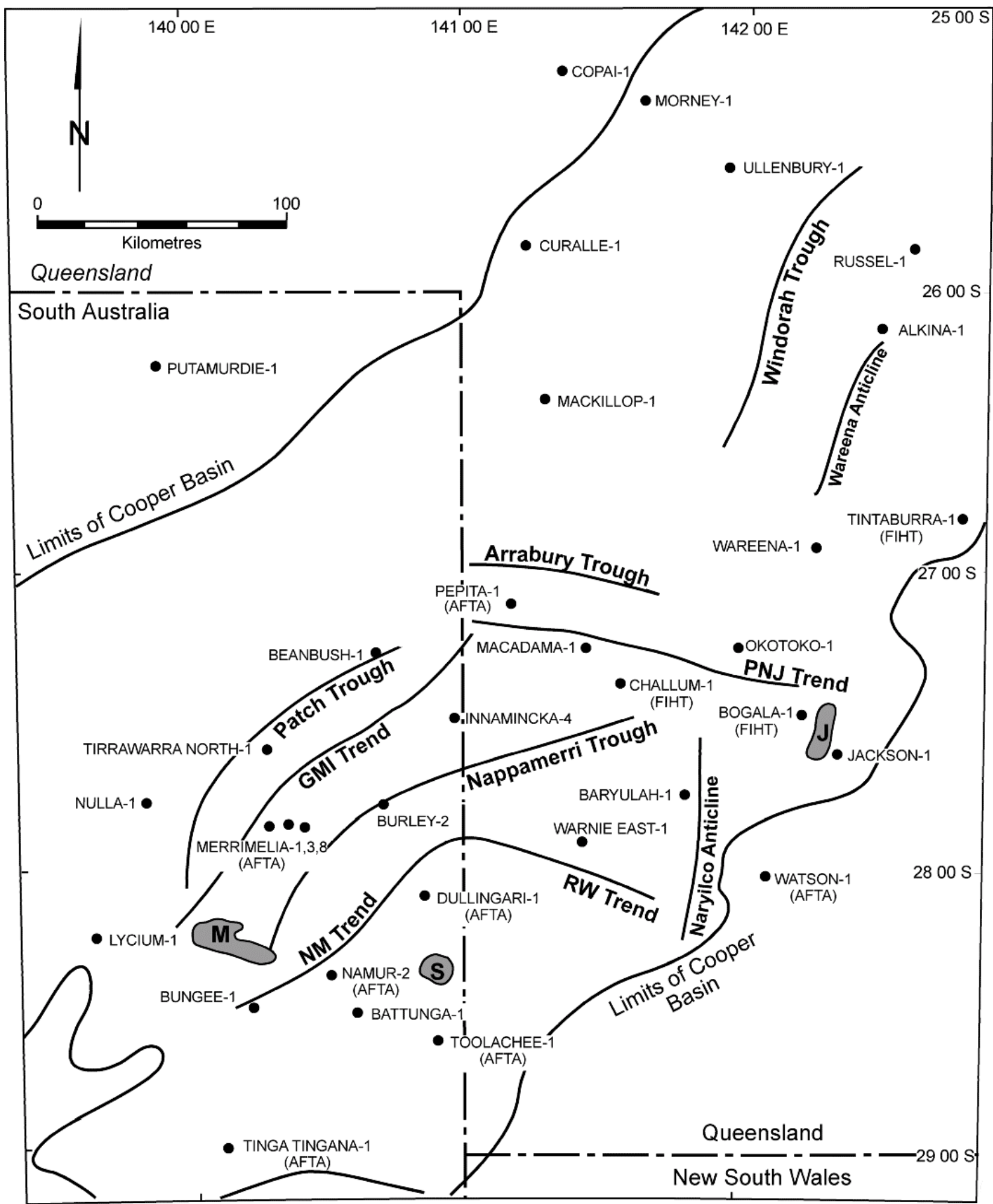

Fig. (3). Location of wells reported with sonic, vitrinite reflectance, AFTA and FIHT studies, major tectonic elements and oil fields are also shown. (GMI = Gidgealpa-Merrimelia-Innamincka, $\mathrm{J}=$ Jackson Field, $\mathrm{M}=$ Moomba Field, NM = Nappacoongee-Murteree, Patch $=$ Patchawarra, PNJ = Pepita-Naccowlah-Jackson South, RW = Roseneath-Wolgolla, $\mathrm{S}=$ Strzelecki).

Why studying exhumation? Exhumation from maximum burial-depth influences multiple problems pertaining to hydrocarbon exploration. The generation of hydrocarbons and migration occurs not within the present structural framework of the basin, but within a framework modified by subsequent exhumation. Hence, if the magnitude of exhumation is quantified it can be used to better predict source rock maturity and to reconstruct basin morphology at the time of hydrocarbon migration and hence elucidate pre-exhumation migration pathways [3-6]. 
Additionally, porosities and seismic velocities in the basin are generally attained at burial-depths greater than that presently observed. Prediction of these parameters should incorporate the (quantified) effects of exhumation from maximum burial-depth. Beyond its significance to petroleum exploration, quantifying exhumation is critical for reconstructing the evolutionary process of the basin formation [9]. The main purpose of this article is the evaluation of exhumation during the major hiatuses taking into account all the estimates from several applied methods (compaction, apatite fission track analysis-AFTA, sonic, vitrinite reflectance and fluid inclusion homogenization temperature method- FIHT). The final synthesized model can be useful for any future drilling activity.

\section{COMPARISON OF APPARENT EXHUMATION ES- TIMATES}

The amount of elevation of exhumed sedimentary rocks above their maximum burial depth reported as apparent exhumation [8] and is common terminology in hydrocarbon exploration.

As discussed in [10] apparent exhumation estimates based on the sonic log are considered more reliable than those based on the other logs. Hence, sonic log-based estimates of exhumation are used for the comparisons in this article. As given in detail in [5] over maturity witnessed by vitrinite reflectance can be ascribed to exhumation from previously greater burial-depth and/or higher palaeogeothermal gradients. Thus, exhumation values obtained from vitrinite reflectance are strongly influenced by the palaeogeothermal history that is selected.

The apparent exhumation values derived from the sonic log for the Eromanga Basin sequence are comparable with, or greater than those acquired from vitrinite reflectance $(\mathrm{Ta}-$ ble 1 and Fig. (4)).

The differences between apparent exhumation values for the two techniques are less than $350 \mathrm{~m}$ except at Innamincka4, Jackson-1, and Warnie East-1, where the differences are

Table 1. Apparent Exhumation Estimates ${ }^{1}$

\begin{tabular}{|c|c|c|c|c|c|c|}
\hline \multirow{3}{*}{ Well } & \multicolumn{6}{|c|}{ Apparent Exhumation (in Metres) Estimates Based on the Following Methods } \\
\hline & \multicolumn{2}{|c|}{ SITT } & \multicolumn{2}{|c|}{ VR } & \multirow{2}{*}{$\begin{array}{c}\text { AFTA } \\
\text { Eromanga }\end{array}$} & \multirow{2}{*}{$\begin{array}{c}\text { FIHT } \\
\text { Eromanga }\end{array}$} \\
\hline & Eromanga & Cooper & Eromanga & Cooper & & \\
\hline Alkina-1 & 529 & 914 & 200 & 540 & & \\
\hline Baryulah-1 & 366 & 852 & 600 & 870 & & \\
\hline Battunga-1 & 302 & 619 & 250 & 380 & & \\
\hline Beanbush-1 & 67 & 159 & 0 & 190 & & \\
\hline Bogala-1 & 578 & 944 & & & & 380 \\
\hline Bungee-1 & 278 & 660 & 0 & 250 & & \\
\hline Burley-2 & 385 & $204^{2}$ & 200 & 1730 & & \\
\hline Copai-1 & 531 & I.M & 300 & I.M & & \\
\hline Challum-1 & 389 & 839 & & & & 190 \\
\hline Curalle-1 & 996 & $839^{2}$ & 800 & 1190 & & \\
\hline Innamincka-4 & 666 & 896 & 0 & 310 & & \\
\hline Jackson-1 & 775 & 814 & 400 & 710 & 457 & 280 \\
\hline Lycium-1 & 250 & 342 & 150 & 310 & & \\
\hline Macadama-1 & 336 & 387 & 300 & 500 & & \\
\hline Mackillop-1 & 446 & 682 & 350 & 470 & & \\
\hline Morney-1 & 824 & $798^{2}$ & & & 975 & \\
\hline Nulla-1 & 230 & 625 & 300 & 610 & & \\
\hline Okotoko-1 & 517 & 975 & 350 & 620 & & \\
\hline Pepita-2 & 431 & 806 & & & 460 & \\
\hline Putamurdie-1 & 542 & I.M & 230 & I.M & & \\
\hline Russel-1 & 337 & 705 & 350 & 480 & & \\
\hline Tirrawarra North-1 & 185 & 376 & 0 & 400 & & \\
\hline Ullenbury-1 & 453 & $310^{2}$ & 520 & 690 & & \\
\hline Wareena-1 & 871 & 1142 & 800 & 1180 & & \\
\hline Warnie East-1 & 542 & 906 & 60 & 380 & & \\
\hline Watson-1 & 613 & I.M & & I.M & 549 & \\
\hline
\end{tabular}

SITT: Sonic interval transit time; VR: Vitrinite reflectance; AFTA: Apatite fission track analysis; FIHT: fluid inclusion homogenization temperature; IM: Interval Missing.

${ }^{1}$ Wells without apparent exhumation values means that no data have been collected (i.e. in VR) or reported (i.e. in AFTA and FIHT).

${ }^{2}$ Values where exhumation derived from Cooper Basin units is less than exhumation derived from Eromanga Basin units, i.e. no distinct phase of pre-Eromanga Basin exhumation can be distinguished. 


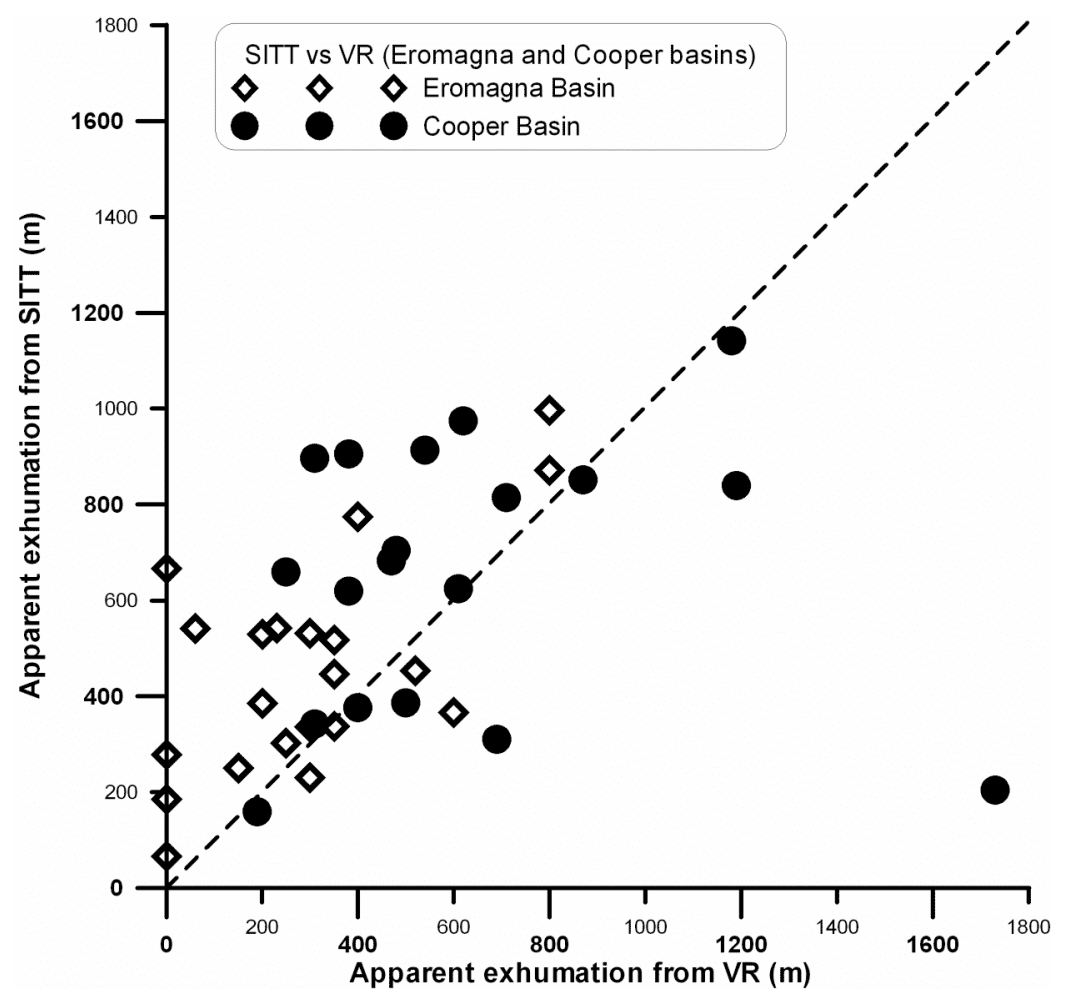

Fig. (4). Comparison of apparent exhumation (in meters) from two different methods: (a) compaction based (sonic log) values from Eromanga Basin sequence (empty squares) versus those from vitrinite reflectance, (b) compaction based (sonic log) values from Cooper Basin sequence (circles) versus those from vitrinite reflectance,

650,370 and $480 \mathrm{~m}$, respectively (Table 1). In the case of the Cooper Basin sequence, the majority of the wells show apparent exhumation values derived from the sonic log that are broadly comparable with those derived from vitrinite reflectance (Table 1 and Fig. (4)).

Again, the differences between apparent exhumation values from the two techniques are less than $350 \mathrm{~m}$ except at Bungee-1, Innamincka-4, and Warnie East-1, where the differences are 400, 580 and $520 \mathrm{~m}$, respectively. The greatest difference is observed at Burley-2, where the vitrinite reflectance method suggests some $1500 \mathrm{~m}$ more apparent exhumation than the compaction analysis. The broad patterns of apparent exhumation revealed by the compaction and vitrinite reflectance methods are comparable [5]. Both methods suggest lower Late Cretaceous-Tertiary apparent exhumation values in the Patchawarra Trough and the Nappamerri Trough and an increase in apparent exhumation in the Jackson-Naccowlah area (to approximately 600m) and the Curalle anticline (to approximately $1000 \mathrm{~m}$ ).

The reported apparent exhumation values from the AFTA and FIHT methods [6] are also in broad agreement with those extracted from compaction analysis (Table $\mathbf{1}$ and Figs. $(5,6))$.

The greatest difference is at the Jackson-1 well, where compaction analysis gives values 300 and $500 \mathrm{~m}$ greater than those from the AFTA and FIHT, respectively.

There were clearly much more data available from compaction and vitrinite reflectance-based methods than from AFTA and FIHT. The compaction and vitrinite reflectance methods have the advantage over the other methods in that they are based on data that are commonly available from exploration wells and do not necessarily require extra laboratory tests and costs.

The authors do not feel able to say with confidence which method(s) are more accurate such would seem to require knowledge of 'true' exhumation values. However, given that, albeit with some exceptions, the compactionbased values of apparent exhumation derived from the sonic $\log$ are consistent with those based on the other techniques, and that the compaction-based data provides the most extensive set of results, these data are considered the best available for characterizing exhumational events in the CooperEromanga Basins.

However, in order to determine burial/exhumation histories for the Cooper-Eromanga Basins it is also necessary to constrain, as far as possible, the timing of the major periods of exhumation. The timing of these events is discussed in [3].

\section{IMPLICATIONS TO EXPLORATION}

The Cooper Basin, underlying the Eromanga Basin was, of course, subject to the same Late Cretaceous - Tertiary exhumation that is witnessed by the overcompaction of the units analyzed in the Eromanga Basin sequence. However, the Cooper Basin appears, at least locally, to have been subjected to a more major period of exhumation in Late Triassic - Early Jurassic times, prior to the deposition of the Eromanga Basin $[3,4]$. Given $\mathrm{a} \pm 200 \mathrm{~m}$ error on apparent exhumation values from individual units, the excess of Cooper Basin apparent exhumation over that of the Eromanga Basin is within error limits [4]. However, there are significant areas 


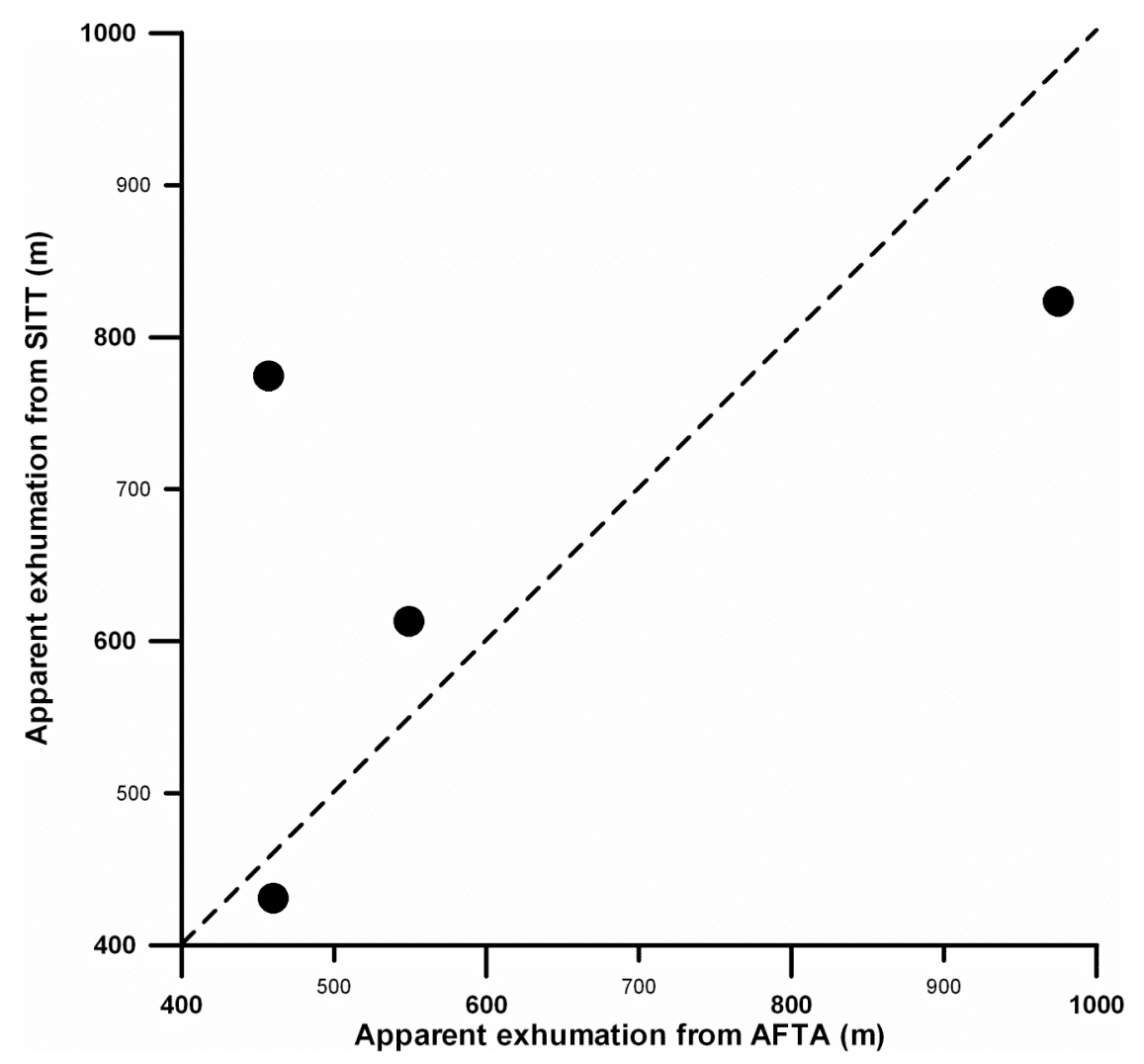

Fig. (5). Compaction based (sonic log) values from Eromanga Basin sequence versus those from AFTA.

where the difference is in excess of $400 \mathrm{~m}$, and, perhaps even more importantly, the map of the difference between Cooper and Eromanga Basin apparent exhumation (Fig. 7) has a demonstrable link with the structural history of the basins.

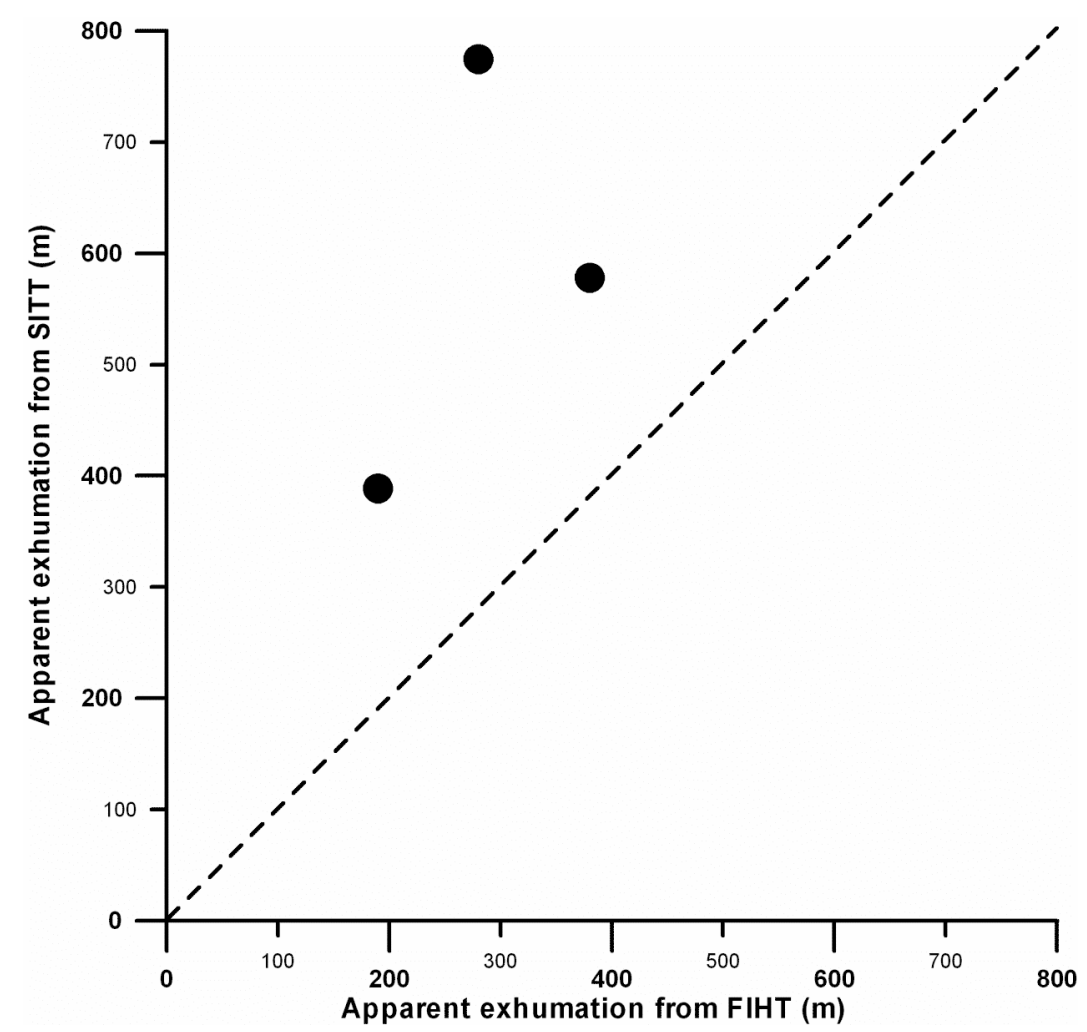

Fig. (6). Compaction based (sonic log) values from Eromanga Basin sequence versus those from fluid inclusion homogenization temperatures- FIHT. 


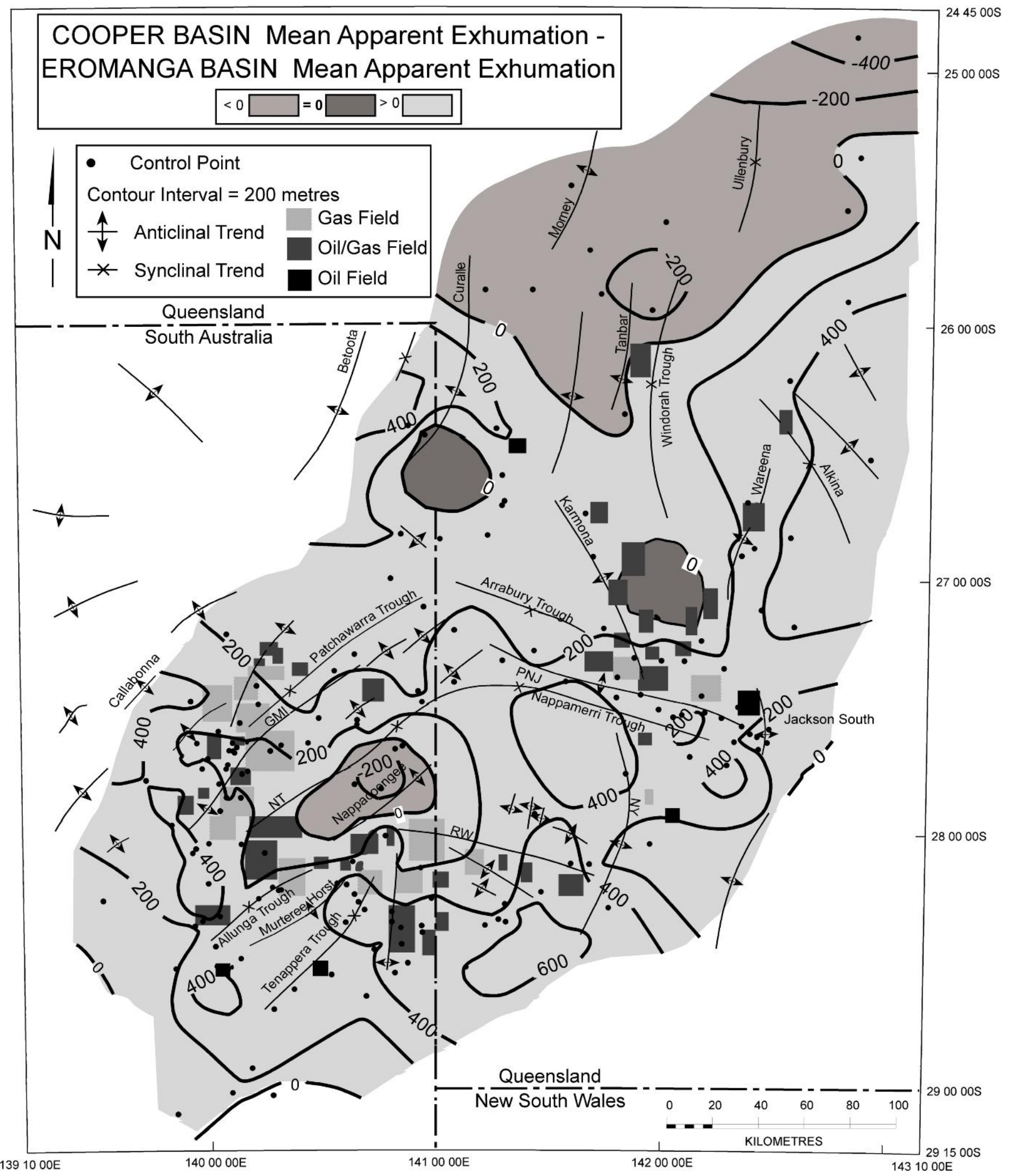

Fig. (7). Map showing the difference between mean apparent exhumation in Cooper Basin and Eromanga Basin [4]. Major fields, well control points and tectonic elements are also shown.

The major Troughs within the Cooper-Eromanga Basins: Patchawarra, Nappamerri, Arrabury and Windorah, which were depocentres during the development of the Cooper Basin $[11,12,13]$, correspond with areas where maximum burial-depth was attained subsequent to the deposition of the
Eromanga Basin. Some of the areas where Cooper Basin apparent exhumation is significantly greater than that of the Eromanga Basin are Permo-Triassic structural highs such as the Callabonna anticline, Pondrinie, Naccowlah and a significant area centred on the Toolachee Field. 
A major region of hydrocarbon accumulations from Fly Lake through Gidgealpa, Moomba and Della lie between the Nappamerri Trough, where maximum burial-depth was attained after deposition of the Eromanga Basin, and a NNWSSE trending axis where the Cooper Basin attained maximum burial-depth prior to the deposition of the Eromanga Basin. The Toolachee and surrounding fields are located in another region where the Cooper Basin attained maximum burial-depth prior to the deposition of the Eromanga Basin. Given that Permian-sourced oils are highly unlikely to be preserved where the sources attained maximum burial-depth prior to the deposition of the Eromanga Basin, it is suggested that the Nappamerri Trough, or other more local areas where maximum burial-depth was attained after deposition of the Eromanga Basin, are the primary source of Permian hydrocarbons. This implies some degree of lateral migration of these hydrocarbons to reservoirs located on structural highs where maximum burial-depth was attained prior to the deposition of the Eromanga Basin.

\section{INFLUENCE OF EXHUMATION ON SOURCE ROCK MATURITY}

Quantification of the timing and magnitude of exhumation is of critical importance to the understanding of petroleum systems in exhumed basin settings. The combination of any given palaeogeothermal gradients with a burial history plot for a potential hydrocarbon source that allows for exhumation normally indicates earlier and higher levels of organic maturity than with a burial history plot that does not allow for exhumation. Thus, estimates of exhumation, such as those presented, should be incorporated in maturation modeling of wells not at their maximum burial-depth.

\section{DISCUSSION AND CONCLUSIONS}

A question that continues to be debated amongst explorationists in the Cooper-Eromanga Basins is whether the hydrocarbons located in Eromanga reservoirs were sourced primarily from rocks in the Eromanga Basin or those in the Cooper Basin. In the Cooper Basin, the location of oil and gas fields is closely linked to the distribution of maturity in the source rocks. For example, most of the gas fields are located in or near the hot Nappamerri Trough, whereas the cooler Patchawarra Trough is the area of the oil fields [14, 15]. In the Eromanga Basin, the distribution of oil and gas is not so closely related to surrounding maturation levels [15]. Most of the oil pools in the Eromanga Basin are located over and adjacent to the margins of the Cooper Basin [13].

Stratigraphically the Eromanga fields are characterized by vertically stacked pools, with the largest accumulation of oil usually located just below the deepest, most competent seal [13]. The same author [13], used the above and other factors to argue that much of the oil and gas in the Eromanga Basin was sourced from the underlying Cooper Basin. A drilling program carried out at the edge of southwestern Cooper Basin, where the confining Nappamerri 'bed' is absent, largely confirmed this hypothesis, yielding commercial discoveries of oil in Eromanga reservoirs that are hydraulically connected to the underlying Cooper source rocks [13]. A chemical biomarker study by [16] supports the field-based conclusions for a dominantly Permian source for Eromanga hydrocarbons. If the oil and gas reservoir in the Eromanga Basin are sourced largely from underlying Cooper rocks, as the above arguments suggest, then the timing of the oil and gas generation and expulsion relative to the creation of trapping structures in the Eromanga Basin is very critical. For example, if the oil was generated and expelled from source rocks before structures were formed, such as during the burial/exhumation of the Cooper Basin, then no significant accumulations would be expected to be found. This hypothesis has been used to explain the absence of hydrocarbon discoveries in many Eromanga structures that would have expected to yield oil or gas [14].

Where the excess of Late Triassic - Early Jurassic exhumation over subsequent burial is relatively small:

- Cooper Basin sourced oils could have directly charged Eromanga Basin reservoirs

- Cooper Basin reservoirs may have been charged with Cooper Basin sourced oils in Late Tertiary times, and such oils need not have been preserved in reservoirs since Late Triassic - Early Jurassic times.

This is evident in Jackson and Tirrawarra areas (Fig. 7) where the Late Triassic - Early Jurassic exhumation over subsequent burial is relatively small, and maturities attained by Cooper Basin source rocks in Tertiary times are higher than were attained in Late Triassic - Early Jurassic times. Hence, hydrocarbons generated by Cooper Basin source rocks could have charged reservoirs in these areas in Tertiary times.

However, it is unlikely that Cooper Basin sources could have filled Eromanga Basin reservoirs if Late Triassic Early Jurassic exhumation over subsequent burial is in excess of at least $400 \mathrm{~m}$. For detailed estimates for each well the reader is referred to [3-6].

Indeed geochemical work of [17] has suggested that Eromanga Basin sourced oils form a significant component of Eromanga Basin reservoired oils. However, future research may investigate whether areas where Cooper Basin sources are currently at maximum maturity coincide with areas where Cooper Basin sourced oils dominate, and whether areas where Cooper Basin sources have not reattained maturity levels attained in Late Triassic - Early Jurassic are dominated by Eromanga Basin sourced oils.

\section{REFERENCES}

[1] R.C.N. Thornton, "Regional stratigraphic analysis of the Gidgealpa Group, Southern Cooper Basin, Australia," South Australia Geological Survey Bulletin, vol. 49, pp. 140, 1979.

[2] A. Mavromatidis, "Quantification of Exhumation in the CooperEromanga basins and its implications for hydrocarbon exploration," $\mathrm{PhD}$ thesis, The University of Adelaide, Australia, 1997.

[3] A. Mavromatidis, "Burial/exhumation histories for the CooperEromanga Basins and implications for hydrocarbon exploration, Eastern Australia," Basin Research, vol. 18, pp. 351-373, 2006.

[4] A. Mavromatidis, "Quantification of exhumation from sonic velocity data, Cooper Basin, Australia and implications for hydrocarbon exploration," Surveys in Geophysics; vol. 27, pp. 277-317, 2006.

[5] A. Mavromatidis, "Exhumation study in the Cooper-Eromanga Basins, Australia and the implications for hydrocarbon exploration," Energy Sources, vol. 29(A), pp. 631-648, 2007.

[6] A. Mavromatidis, "Evidence of exhumation from apatite fission track analysis and fluid inclusion homogenization temperatures in the Cooper-Eromanga Basins, Australia," Energy Sources, vol. 29(A), pp. 741-751, 2007.

[7] O.W. Bowering, "Hydrodynamics and hydrocarbon migration. A model for the Eromanga Basin," Journal of Australian Petroleum 
Production and Exploration Association, vol. 22, pp. 227-236, 1982.

[8] A. Mavromatidis and R. Hillis, "Quantification of exhumation in the Eromanga Basin and its implications for hydrocarbon exploration," Petroleum Geoscience, vol. 11, pp. 79-92, 2005.

[9] A. Mavromatidis, "Two layer model of lithospheric compression and uplift/exhumation in an intracratonic setting: an example from the Cooper-Eromanga Basins, Australia," International Journal of Earth Sciences, doi 10.1007/s00531-007-0260-5, 2007.

[10] A. Mavromatidis, "Combined analysis of different logs in quantification of exhumation and its implications for hydrocarbon exploration, a case study from Australia," Geologica Acta, vol. 4, pp. 355370, 2006.

[11] M. Zwigulis, "Permian Geology of the Cooper Basin in Queensland," in proceedings of the Symposium on the Permian Geology of Queensland, Brisbane Geological Society of Australia Queensland Division, July 14-16, 1983, pp. 43-49.

[12] W.J. Stuart, S. Kennedy, and A.D. Thomas, "Influence of structural growth and other factors on the configuration of fluvial sandstones, Permian Cooper Basin," Australian Petroleum Exploration Association Journal, vol. 28, pp. 255-265, 1988.

[13] R.S. Heath, S. McIntyre, and N. Gibbins, "A Permian origin for Jurassic reservoired oil in the Eromanga Basin," in proceedings of the Cooper and Eromanga Basins Conference, Adelaide, Petroleum Exploration Society of Australia, Society of Petroleum Engi- neers, Australian Society of Exploration Geophysicists (South Australia Branches), B.J. O'Neil, (Ed), 1989, pp. 405-416.

[14] A.J. Kantsler, T.J.C. Prudence, A.C. Cook, and M. Zwigulis, "Hydrocarbon habitat of the Cooper/Eromanga Basin, Australia," Australian Petroleum Exploration Association Journal, vol. 23, pp. 7592, 1983.

[15] J.W. Hunt, R. Heath, and P.E. McKenzie, "Thermal maturity and other geological controls on the distribution and composition of Cooper Basin hydrocarbons," in proceedings of the Cooper and Eromanga Basins Conference, Adelaide, Petroleum Exploration Society of Australia, Society of Petroleum Engineers, Australian Society of Exploration Geophysicists (South Australia Branches), B.J. O'Neil, (Ed), 1989, pp. 509-524.

[16] C.C. Jenkins, "Geochemical correlation of source rocks and crude oils from the Cooper and Eromanga Basins," in proceedings of the Cooper and Eromanga Basins Conference, Adelaide, Petroleum Exploration Society of Australia, Society of Petroleum Engineers, Australian Society of Exploration Geophysicists (South Australia Branches), B.J. O'Neil, (Ed), 1989, pp. 525-540.

[17] B.H. Michaelsen and D.M. McKirdy, "Organic facies and petroleum geochemistry of the lacustrine Murta Member (Mooga Formation) in the Eromanga Basin, Australia," in proceedings of the Cooper and Eromanga Basins Conference, Adelaide, Petroleum Exploration Society of Australia, Society of Petroleum Engineers, Australian Society of Exploration Geophysicists (South Australia Branches), B.J. O'Neil, (Ed), 1989, pp. 541-558. 